\title{
O tyranii i cnocie politycznej. Uwagi na marginesie książki Romualda Piekarskiego Koncepcja cnót politycznych Machiavellego na tle elementów klasycznej etyki cnóf*
}

DOI: http://dx.doi.org/10.12775/RF.2014.005

Bardzo ogólnie rzecz ujmując, można zaryzykować stwierdzenie, że we współczesnej literaturze przedmiotu dominują dwa sposoby patrzenia na dzieło Niccolò Machiavellego. Pierwszy z nich, który określić można mianem filozoficznego, akcentuje pojęcie cnoty politycznej, jakim operował myśliciel z Florencji, i próbuje dokonać jego analizy i oceny, odnosząc je też do innych koncepcji cnót. Niewątpliwie wzorzec takiego podejścia stworzył Leo Strauss, według którego Machiavelli był radykalnym innowatorem $\mathrm{w}$ dziedzinie myśli, gdyż odarł wszystkie religie ze świętości i tajemnicy, przedstawiając je jako twory polityczne, a jednocześnie - przy całej fascynacji republiką rzymską i kultywowanym w niej wzorcem życia publicznego - poddał głębokiemu przewartościowaniu antyczny model cnoty ${ }^{1}$.

* Autor jest doktorem nauk prawnych, pracownikiem Państwowej Wyższej Szkoły Zawodowej im. Angelusa Silesiusa w Wałbrzychu.

** Zob. R. Piekarski, Koncepcja cnót politycznych Machiavellego na tle elementów klasycznej etyki cnót, Wyd. UG, Gdańsk 2007.

1 Zob. L. Strauss, Thoughts on Machiavelli, Glencoe, Illinois, 1958, s. 9-12, 175; idem, Niccolò Machiavelli, przeł. A. Lipszyc, w: Historia filozofii politycznej. Podręcznik, red. L. Strauss, J. Cropsey, red. nauk. P. Nowak, M. Wiśniewski, Fundacja Augusta hr. Cieszkowskiego - Fronda, Warszawa 2010, s. 301-318; idem, Machiavelli's Intention: The Prince, „The American Political Science Review” 1957, vol. 51, no. 1, s. 34-38. 
Drugi ze sposobów postrzegania dorobku Machiavellego dąży z kolei do właściwego odczytania go w kontekście dyskursu politycznego czasów, w których tworzył. Nie bez racji nazwać go zatem można historyzującym albo kontekstualnym, a jego początki wiązać wypada z pojawieniem się interpretacji ukazujących koncepcje florentczyka przez pryzmat biografii autora bądź też zawartej w nich recepcji dorobku intelektualnego starożytności. Współcześnie jako zwolennicy analiz kontekstualnych deklarują się reprezentanci "szkoły z Cambridge”, badający dziedzictwo europejskiego republikanizmu. Quentin Skinner, uchodzący za przywódcę tej szkoły, ukazywał Księcia Machiavellego na tle ówczesnego gatunku literatury politycznej, jakim były tzw. zwierciadła monarsze (specula principis), na tej podstawie poszukując tego, co w tym utworze rzeczywiście indywidualne i wyjątkowe, a przy tym próbując obalić niektóre zadawnione opinie na jego temat ${ }^{2}$. John G. A. Pocock natomiast, $\mathrm{w}$ monumentalnej monografii The Machiavellian Moment, traktuje doktrynę florenckiego pisarza politycznego jako jeden z kamieni milowych - "momentów" w rozwoju zachodniego dyskursu republikańskiego, którego kolejne „momenty” miały miejsce w Anglii drugiej połowy XVII w., osiemnastowiecznej Szkocji i wreszcie w refleksji ojców założycieli Stanów Zjednoczonych ${ }^{3}$. Dwa nakreślone tutaj nurty badań nad Machiavellim wyznaczają ramy prowadzonych współcześnie badań, jakkolwiek istnieją też interpretacje, które próbują łączyć elementy przynależne do obu.

Trzeba zauważyć, że już bardzo wcześnie w polskiej literaturze przedmiotu podjęty został problem koncepcji cnoty u Machiavellego, rozważany w pochodzącej z końca XIX w. pracy Witołda Skarżyńskiego $^{4}$. Rodzime badania nad Machiavellim na kilka ostatnich dziesięciole-

2 Na temat Księcia - zob. Q. Skinner, The Foundations of Modern Political Thought. Volume One: The Renaissance, Cambridge University Press, Cambridge 1990, s. 118-138 (Quentin Skinner argumentuje, że cele, jakie Machiavelli stawiał przed władca, były dokładnie takie same, jak te, które zarysowywali autorzy „zwierciadeł monarszych", różnica polega jedynie na dopuszczalnych metodach ich osiągnięcia). W innej pracy brytyjski uczony chce czytelników przekonać, że tezy Machiavellego pozostawały zasadniczo koherentne $\mathrm{z}$ humanistycznym republikanizmem XV w. Zob. idem, Machiavelli's Discorsi and the pre-humanist origins of republican ideas, w: Machiavelli and Republicanism, eds. G. Bock, Q. Skinner, M. Viroli, Cambridge University Press, Cambridge 1990, s. 135-141.

3 Zob. J. G. A. Pocock, The Machiavellian Moment: Florentine Political Thought and the Atlantic Republican Tradition, Princeton 1975, s. 184 i n.

4 Zob. W. Skarżyński, Mikołaj Machiavel a Andrzej Frycz Modrzewski, Towarzystwo Przyjaciół Nauk Poznańskie, Poznań 1898, s. 19 i n. Wcześniejsze polskie prace dotyczące Niccolò Machiavellego wydobywały z jego myśli raczej wątki republikańskie i ideę zjednoczenia Włoch. Por.: L. S. [L. Siemieński], Machiawelli [sic!] i jego system polityczny. Z dodaniem aforyzmów, Lipsk 1851, s. 36-44 (pierwsza monografia Machiavellego napisana przez polskiego autora); L. Żychliński, Machiawell, jego życie 
ci XX w. zdominowały jednak dociekania z zakresu historii idei, których celem było przede wszystkim osadzenie dzieła i postaci autora Księcia w kontekście włoskiego i europejskiego odrodzenia. Takie bowiem zamierzenie przyświecało klasycznym już publikacjom Antoniny Kłoskowskiej ${ }^{5}$, a zwłaszcza Jana Malarczyka, przy czym ten ostatni uczony porównywał doktryny Machiavellego i nieco młodszego odeń Francesca Guicciardiniego, chcąc wskazać elementy włoskiego renesansowego realizmu politycznego ${ }^{6}$. Wszakże w ostatnich latach, oprócz kilku przekładów, polska literatura wzbogaciła się o trzy monografie, które - każda w bardzo odmienny sposób - wprowadzają nowe elementy do dotychczasowych analiz. Są to mianowicie dzieła: Igora Kąkolewskiego Melancholia władzy. Problem tyranii w europejskiej kulturze politycznej XVI stulecia (Warszawa 2007), Piotra Kimli Historycy-politycy jako źródło realizmu politycznego. Tukidydes - Polibiusz - Machiavelli (Kraków 2009) oraz Romualda Piekarskiego Koncepcja cnót politycznych Machiavellego na tle elementów klasycznej etyki cnót (Gdańsk 2007). Wszystkie te książki, choć - co trzeba na wstępie podkreślić - odznaczają się rozmachem badawczym i erudycją są bardzo odmienne pod względem przyjętych założeń metodologicznych, jak też celów badawczych. W niniejszym szkicu skoncentruję się na ostatniej z wymienionych książek, próbując ustalić, czym wyróżnia się ona na tle wymienionych pozycji.

Piekarski na wstępie wskazuje, że zgłębienie podjętego przezeń tematu „powinno umożliwiać m.in. bardziej wnikliwą obserwację i ocenę współczesnych patologii i dysfunkcji życia politycznego"7. Już samo to sformułowanie sugeruje, że nie odkrycie tła historycznego czy intelektualnego klimatu piętnastowiecznej Florencji będzie głównym zamierzeniem autora. Tak też jest $\mathrm{w}$ istocie $\mathrm{i} \mathrm{w}$ tym wyraża się niewątpliwie zasadnicza różnica między jego podejściem a perspektywą obraną przez Kąkolewskiego, który dąży do zrekonstruowania obrazu tyranii w kul-

i pewne wybitne strony zawarte w jego dwóch głównych pismach historyczno-politycznych. Rozprawa czytana w Towarzystwie Poznańskiem Przyjaciót Nauk na d. 4. marca r. b. przez Ludwika Żychlińskiego, Wydawca Ludwik Merzbach, Poznań 1861, s. 13-18. Warto tutaj dodać, że w okresie I Rzeczypospolitej florencki autor nie cieszył się popularnością, a jego prace były potępiane (takie stanowisko przedstawił Chryzostom Piekarski w ogłoszonej w 1662 r. rozprawie: Cnoty cel nie ów, do którego zmierza Machiawell i inni w Akademii onegoż promowowani politycy, odkryty piórem polskim przez Chryzostoma z Piekar Piekarskiego podkomorzego brzeskiego).

5 Zob. A. Kłoskowska, Machiavelli jako humanista na tle włoskiego Odrodzenia, Prace z Historii Myśli Społecznej, t. 4, Łódzkie Towarzystwo Naukowe, Zakład im. Ossolińskich, Wrocław-Łódź 1954.

6 Zob. J. Malarczyk, U źródet włoskiego realizmu. Machiavelli i Guicciardini, Wyd. UMCS, Lublin 1963; idem, Doktryna polityczna Machiavellego, „Annales Universitatis Mariae Curie-Skłodowska. Sectio G", 1962, nr 9, z. 6.

7 R. Piekarski, Koncepcja cnót politycznych Machiavellego, s. 9. 
turze politycznej renesansu' ${ }^{8}$. Stąd też, wzorem Skinnera, konfrontuje on teksty Machiavellego ze "zwierciadłami monarszymi”, w tym z „arcyzwierciadłem", jakim jest dlań dzieło Erazma z Rotterdamu Institutio Principis Christiani ${ }^{9}$. Dochodzi przy tym do wniosku, że traktaty Machiavellego i Erazma "stanowią dwugłos w toczonej na początku XVI w. humanistycznej debacie nad rolą przemocy w polityce"10. O ile jednak Erazm pragnął polityki bez przemocy i taki też ideał (czy, jak chcieliby niektórzy, utopię) prezentował „księciu chrześcijańskiemu”, o tyle Machiavelli - jak zaznacza Kąkolewski - uznawał użycie siły przez „nowego księcia" (il principe nuovo) za niekiedy wybawienie dla republiki w upadku ${ }^{11}$. Taki właśnie obraz księcia, będący zrelatywizowanym $\mathrm{i}$ „wysublimowanym [...] odbiciem tyrana”"12, jest dla Kąkolewskiego kluczem do zrozumienia szesnastowiecznego dyskursu o tyranii ${ }^{13}$, a także początkiem procesu, który ostatecznie w XIX w. doprowadził do nadania takim terminom, jak "despocja”, "dyktatura”, ale również "tyrania", bardziej neutralnej konotacji. Zaczęły one bowiem być stosowane na oznaczenie - przejawiającej się w najrozmaitszych koncepcjach - swoistej przejściowej formy rządów. Taka „złagodzona” koncepcja tyranii znalazła się zaś, jak konstatuje Kąkolewski, u podstaw współczesnego realizmu politycznego ${ }^{14}$.

Ten sam temat - narodzin realizmu politycznego - podjął również Kimla, przy czym obrana przezeń metodologia jest dość typowa dla badaczy myśli politycznej i prawnej, a z pewnością bardziej standardowa niż ta, którą reprezentuje Kąkolewski. Polega ona mianowicie na wy-

8 W pewien sposób książka ta jest kontynuacją wcześniejszych badań Igora Kąkolewskiego nad narodzinami i rozwojem państwa nowożytnego i odpowiadającej mu mentalności. W monografii Nadużycia władzy i korupcja w Prusach Ksiażęcych w połowie XVI wieku wiązał bowiem rozwój państwa nowożytnego z powstaniem etosu urzędniczego (łączącego urząd z dobrem publicznym, a nie prywatnym czy rodzinnym), wprowadzaniem dyscypliny i stopniowym eliminowaniem korupcji wszechobecnej w państwie wczesnonowożytnym, które można postrzegać jako swoiste przedsiębiorstwo „handlujące władzą”. Zob. I. Kąkolewski, Nadużycia władzy i korupcja w Prusach Ksiażęcych w połowie XVI wieku. Narodziny Państwa wczesnonowożytnego, Wyd. „Trio", Warszawa 2000, s. 137-202.

9 Jakkolwiek użyte przez Kąkolewskiego pod adresem dzieła Erazma określenie: „wzór ówczesnego kanonu politycznej poprawności” - można uznawać za nietrafioną gdyż obciążoną nadmiernym prezentyzmem metaforę. Zob. idem, Melancholia władzy. Problem tyranii w europejskiej kulturze politycznej XVI stulecia, Wyd. Neriton, Warszawa 2007, s. 101.

10 Ibidem, s. 126.

11 Por. ibidem, s. 85-86.

12 Ibidem, s. 66.

13 Relatywizacja ta prowadziła do przekonania - które w tamtej epoce głosili nawet tak radykalni przeciwnicy Machiavellego jak Erazm z Rotterdamu - że tyrania lepsza jest od anarchii.

14 Por. ibidem, s. 426-437. 
borze kilku myślicieli z dość odległej przeszłości, których - zdaniem autora - można uznać za prekursorów czy też fundatorów realizmu politycznego, i poddaniu skrupulatnej analizie ich dorobku pod kątem dokładniejszego zdefiniowania na ich podstawie pojęcia "realizm polityczny". Za jego wyróżniki Kimla uznaje: empiryzm, poleganie na doświadczeniu historycznym, dążenie do obiektywności analizy rzeczywistości politycznej, uznanie władzy za gwaranta ładu instytucjonalnego, dominację polityki zagranicznej nad wewnętrzną, koncentrację na kulturze materialnej, a także dokonywanie ocen z perspektywy skuteczności i unikanie moralizatorstwa ${ }^{15}$. Na tym tle Ksiązę Machiavellego odczytywany jest - co zresztą jest interpretacją nienową i znajdującą uzasadnienie w tekście florenckiego polityka - jako władca odpowiedni na czasy zapaści, którego celem ma być odbudowa państwa oraz zagwarantowanie ładu i bezpieczeństwa mieszkańcom ${ }^{16}$. W takiej jednak perspektywie kwestia tego, czy Machiavelli odciął się od klasycznego rozumienia cnót politycznych, staje się drugorzędna, ponieważ jakkolwiek rozumiana cnota polityczna nabiera znaczenia jedynie instrumentalnego, ma bowiem służyć zachowaniu władzy i zarazem utrzymaniu dobrostanu państwa ${ }^{17}$.

Przechodząc teraz do publikacji Piekarskiego, trzeba zaznaczyć, że wbrew temu, co sugerowałoby wcześniej przytoczone stwierdzenie kontekst historyczny analizowanej myśli bynajmniej nie znika z jej kart, a zatem nie można jej stawiać zarzutów prezentyzmu czy - szerzej anachroniczności. O dbałości o tę warstwę rozważań świadczy zwłaszcza drobiazgowe porównywanie Discorsi sopra la prima Deca di Tito Livio z oryginalnym dziełem Liwiusza, jak też staranna interpretacja poematu Machiavellego I Capitoli, tym bardziej istotna, że twórczość literacka autora Księcia nieczęsto jest przedmiotem pogłębionego zainteresowania badaczy myśli politycznej ${ }^{18}$. Dokładność autora widać także w skrupulatnym porównywaniu polskich edycji z włoskimi oryginałami oraz anglojęzycznymi tłumaczeniami prac florentczyka.

15 Zob. P. Kimla, Historycy-politycy jako źródło realizmu politycznego. Tukidydes - Polibiusz - Machiavelli, Wyd. UJ, Kraków 2009, s. 10-15, 147-159.

16 Por. ibidem, s. 11. Problematykę bezpieczeństwa u Machiavellego Piotr Kimla podkreśla też $\mathrm{w}$ artykule o znamiennym tytule: Wolność jako bezpieczeństwo, w: Idea wolności w ujęciu historycznym i prawnym. Wybrane zagadnienia, red. E. Kozerska, P. Sadowski, A. Szymański, Wyd. Adam Marszałek, Toruń 2010, s. 385-390.

17 Autor uważa, że w przypadku szesnastowiecznej Francji centralizacja władzy i zaprowadzenie rządów absolutnych (zgodnie z postulatami zawartymi w Księciu) umożliwiły zażegnanie wojny domowej i zagwarantowanie spokoju społecznego, w związku z czym rządy takie cieszyły się - przynajmniej początkowo - poparciem poddanych. W sytuacji politycznej Włoch „lekarstwo w postaci silnej władzy skupionej $\mathrm{w}$ jednych rękach okazało się niemożliwe do zastosowania, co nie znaczy, że było niewłaściwe". Zob. idem, Historycy-politycy, s. 11, przyp.

18 Zob. R. Piekarski, Koncepcja cnót politycznych Machiavellego, s. 86-103. 
Zastanawiając się nad statusem dzieła Machiavellego, Piekarski generalnie polemizuje z tymi badaczami, którzy odbierają dziełu florenckiego polityka status przynależności do filozofii, uznając je wyłącznie za zbiór uwag dotyczących taktyki władzy:

O przyznaniu Machiavellemu rangi filozofa politycznego przesądzać się zdaje pewnego rodzaju (żeby to jakoś nazwać) filozoficzna normaty w ność. Wypracowuje on przecież pewną koncepcję dobra wspólnego oraz wzorcowego modelu republiki, mającego przewyższać republikę rzymską okresu jej świetności ${ }^{19}$.

Dodaje jednak, że takie rozstrzygnięcie nie rozwiewa wszystkich wątpliwości co do jego charakteru. Zgodnie z poglądem, który zdaje się dominować we współczesnej literaturze przedmiotu, Piekarski stoi wyraźnie na stanowisku, według którego dwa główne dzieła Machiavellego: Discorsi oraz Il Principe, tworzą ideową jednośćn ${ }^{20}$.

Ponadto już na początku rozważań autor umieszcza ważną deklarację, że postrzega Machiavellego jako innowatora, a novum, jakie miał on wprowadzić do filozofii polityki, polegało na przyjęciu pierwszeństwa polityki zagranicznej nad wewnętrzną. Implikacją tego, zdaniem autora, miałoby być „przeniesienie relacji wojennych (bezwzględnej walki o przetrwanie) do wewnątrz" ${ }^{21}$. Machiavelli ukazuje się więc nie - jak w przytoczonej interpretacji Kimli - jako filozof bezpieczeństwa, w silnej władzy poszukujący sposobu na stabilizację państwa, lecz jako myśliciel, którego koncepcje prowadzą do rozchwiania instytucji państwowych, nawet jeżeli był on zwolennikiem silnej władzy ${ }^{22}$. Jak bowiem nieco dalej badacz stwierdza:

19 Ibidem, s. 40.

20 Ibidem, s. 42-45. Trzeba jeszcze dopowiedzieć, że autor - wskazując na ambicje Machiavellego, by ukazać możliwość przetworzenia instytucji antycznego Rzymu w nową republikę, a później potwierdzając (za Thomasem L. Pangle'em) wpływ Machiavellego na treść esejów Thomasa Gordona i Johna Trencharda z lat 1720-1723, opublikowanych jako Cato letters, a bardzo popularnych wśród walczących o niezależność od Wielkiej Brytanii mieszkańców „Trzynastu Kolonii” - potwierdza istnienie pewnej więzi łączącej Machiavellego z późniejszym, siedemnasto- i osiemnastowiecznym republikanizmem. Por. ibidem, s. 78-82. Na ten temat zob. także: P. Szymaniec, Republikanizm dla społeczeństwa handlowego. Myśl polityczno-prawna Adama Fergusona, Wydawnictwo Uczelniane Państwowej Wyższej Szkoły Zawodowej im. Angelusa Silesiusa, Wałbrzych 2013, s. 52-65.

21 R. Piekarski, Koncepcja cnót politycznych Machiavellego, s. 10.

${ }^{22}$ Zresztą Romuald Piekarski w jeszcze jednym aspekcie nie zgadza się z takimi badaczami, którzy - jak Kimla - upatrują w Machiavellim fundatora realizmu politycznego. Realizm florentczyka opatruje bowiem takimi określeniami, jak „,specyficzny” i „niski”; por. ibidem, s. 15, 468. 
nawet jeśli śmiała hipoteza L. Straussa, że Machiavelli jest odkrywcą i prorokiem nowożytności, okazałaby się nieco przesadzona, to w każdym razie mamy wystarczające świadectwa, że autor Księcia poszukiwał sposobów takiego ulepszenia instytucji republikańskiego Rzymu, żeby jakiś jej zmodernizowany model miał szansę zwyciężyć upadającą cywilizację chrześcijańska, stając się niezwyciężony albo i niezniszczalny ${ }^{23}$.

Zatem - co pokazuje autor - za źródło słabości współczesnej sobie cywilizacji Machiavelli uznawał religię chrześcijańską z głoszonym przez nią modelem cnoty, nakierowanej na świat pozaziemski ${ }^{24}$. Wizję sfery polityki, ukazywaną przez Machiavellego, można więc nie bez racji nazwać neopogańska, jak zresztą czyni to komentowany autor. Konstatacja ta jest niezwykle istotna - $\mathrm{i}$ to niezależnie od tego, czy postrzegamy Machiavellego jako "geniusza zła”, czy też jako odnowiciela myśli republikańskiej. Pokazuje bowiem, że rzeczywiście myśl Machiavellego zrywa z tradycją ${ }^{25}$. Piekarski bardzo szczegółowo zresztą ukazuje - inspirując się zwłaszcza ustaleniami Harveya C. Mansfielda i Leo Straussa - że florencki polityk nie tylko odciął się też od klasycznego, Arystotelesowego rozumienia cnoty, negując podział na cnoty intelektualne i moralne oraz przyznając czynowi prymat nad myśla, ale także dokonując całkowitej reinterpretacji rzymskiego (przede wszystkim Cycerońskiego) modelu cnoty $^{26}$.

23 Ibidem, s. 11 .

24 Według Machiavellego chrześcijaństwo nie faworyzuje ludzi aktywnych, lecz „pokornych, oddanych życiu kontemplacyjnemu”. Wobec tego nie sprzyja budowaniu takich cech, które umożliwiają skuteczne działanie dla państwa - ojczyzny. Zob. N. Machiavelli, Rozważania nad pierwszym dziesięcioksięgiem historii Rzymu Liwiusza, przeł. K. Żaboklicki, ks. 1, XXXVII, w: idem, Wybór pism, oprac. K. Żaboklicki, księga 2, II, PIW, Warszawa 1972, s. 393-394. Jednakże - co też Piekarski trafnie zaznacza Machiavelli uznawał korzyści z instrumentalnego wykorzystywania religii do celów politycznych, a więc jej praktyczną użyteczność.

${ }^{25} \mathrm{~W}$ podobnym kierunku idzie też interpretacja W. Juliana Korab-Karpowicza, różniąca się od odczytania Piekarskiego szczegółami i rozłożeniem akcentów. Badacz ten wykazuje, że - wbrew tezom Isaiaha Berlina - Machiavelli nie buduje dychotomii: społeczeństwo chrześcijańskie albo „szlachetne wspaniałe społeczeństwo" oparte na antycznych, rzymskich wzorcach. Machiavelli odrzuca bowiem klasyczną tradycję refleksji o cnocie jako taka, a więc także dziedzictwo rzymskie, chrześcijańskie oraz humanistyczne, neoplatońskie. Choć jednocześnie w swych wywodach niejednokrotnie w tej tradycji się porusza. Zdaniem Korab-Karpowicza, taki zabieg służy Machiavellemu do tego, by uzasadnić republikanizm, ale odmienny od klasycznego starożytnego oraz piętnastowiecznego, humanistycznego - gdyż oparty na realizmie politycznym i dążeniach militarystycznych (które interpretator może nieco przesadnie uwypukla). Zob. W. J. Korab-Karpowicz, Historia filozofii politycznej. Od Tukidydesa do Locke'a. Tradycja klasyczna i jej krytycy, Wyd. Marek Derewiecki, Kęty 2010, s. 221-233 .

26 Nie zgadzam się jednak z Piekarskim, że „Machiavelli doradza rządzącemu, aby ten nie dbał przesadnie o sprawiedliwość [...]". Zob. R. Piekarski, Koncepcja cnót 
Niepozbawiona podstaw wydaje się teza Piekarskiego, że w Europie, budując więzi o charakterze prawnym czy instytucjonalno-państwowym, od czasów renesansu coraz bardziej odchodzi się od języka cnót (teza ta zresztą zachowuje swoje uzasadnienie niezależnie od tego, czy uważamy Machiavellego za amoralistę i nauczyciela nieprawości, czy też nie; w tym kontekście istotne jest jedynie zrozumienie, że jego ujęcie cnoty jest odmienne od klasycznego). Dochodzimy tu do bardzo ważnej i interesującej warstwy treściowej pracy, zmierzającej do ukazania jej ideowych kontynuacji, zwłaszcza w koncepcjach Maxa Webera i Williama Galstona (przy czym analizę twórczości tego drugiego należy uznać za pionierską $\mathrm{w}$ polskiej literaturze ${ }^{27}$. Jak bowiem akcentuje badacz, dla Webera polityka jest domeną "głowy", czyli myśli i koncepcji, a zatem nie - przynajmniej bezpośrednio - moralności (jakkolwiek trudno Webera, będącego twórcą koncepcji etyki odpowiedzialności, uznawać za nihilistę) $)^{28}$.

politycznych Machiavellego, s. 49. Wydaje mi się bowiem, że zerwanie z klasycznościa, jakie występuje u Machiavellego, nie jest aż tak daleko idące. Machiavelli chce raczej przekonać władcę, że pozostawanie sprawiedliwym w normalnych okolicznościach po prostu się o pła ca. Taką zresztą interpretację - o czym warto nadmienić przedstawił w polskiej literaturze w $1831 \mathrm{r}$. lider stronnictwa kaliszan, Wincenty Niemojowski. Zob. W. Niemojowski, Przedmowa ttumacza, w: B. Constant, O monarchii konstytucyynéy i rękoymiach publicznych. Rzecz wyięta $z$ dzieł Benjamina Constant przekładania Wincentego Niemoiowskiego, cz. 1, Nakładem właścicieli Kuryera Polskiego, Warszawa 1831, s. 21. Dostrzec to można chociażby w następującym fragmencie: „przede wszystkim powinien książę żyć ze swoimi poddanymi w sposób taki, którego nie potrzebowałby zmieniać na skutek żadnego pomyślnego czy niepomyślnego wydarzenia; gdy bowiem pozostawać będziesz pod przymusem czasów burzliwych, za późno już na wyrządzanie ludziom zła, a dobro, które wtedy wyświadczysz, będzie bowiem uważane za wymuszone, więc nie przyniesie ci żadnego uznania". N. Machiavelli, Książę, przeł. Cz. Nanke, w: idem, Ksiązę. Rozważania nad pierwszym dziesięcioksięgiem historii Rzymu Liwiusza, PIW, Warszawa 1984, s. 62 (tak samo zresztą ma być opłacalne dotrzymywanie słowa w relacjach z innymi władcami, jeżeli tylko nadzwyczajne okoliczności nie zmuszają do odstąpienia od tego. Zob. ibidem, s. 103-104). Sprawiedliwość zostaje oparta na użyteczności, zyskuje zatem nowatorskie, odmienne od klasycznego, uzasadnienie. Ponadto wydaje się, że Machiavelli za wzór księcia stawiał Cesarego Borgię (księcia Valentino) nie z tego powodu, iż aprobował jego zbrodnie i niesprawiedliwości. Uważał mianowicie, że cechy Borgii dawały możliwość budowy jednolitego państwa włoskiego. Był więc, wedle Machiavellego jakkolwiek by to brzmiało - tyranem realizującym "dobrą sprawę". Kluczem do zrozumienia Księcia jest bowiem przytoczony na końcu cytat z canzony nr 128 Petrarki Italia mia, wzywającej do wygnania „barbarzyńców” (ț. niemieckich żołnierzy najemnych) z Półwyspu Apenińskiego. Rzecz jasna, przyjęcie takiej interpretacji nie neguje pytania o to, czy cel w istocie usprawiedliwia użyte do jego osiągnięcia środki, a więc Cycerońskiego problemu relacji między utile i honestum.

27 Zob. R. Piekarski, Koncepcja cnót politycznych Machiavellego, s. 371-416.

28 Autor Polityki jako zawodu i powołania dopuszczał sytuacje, w których "dobre” cele wymagać będą użycia wątpliwych, z moralnego punktu widzenia, lub "niebezpiecznych" środków. 
Pluralizm aksjologiczny, który w znacznym stopniu znamionuje współczesne badania nad polityką (z zamierzenia mające być wertfrei), stanowi swoiste dziedzictwo Machiavellego. To oczywiście oddziałuje na przedstawienie $\mathrm{w}$ tych badaniach i ocenę tyranii, które to pojęcie wobec przyjęcia pluralizmu wartości - staje się rozmyte i nieostre. Zauważyć trzeba przy tym, że Kąkolewski i Piekarski - dwaj polscy badacze operujący jakże odmienną metodologią - dochodza, niezależnie od siebie, do bardzo podobnego, przekonującego wniosku. Tym wszakże, co uznać wypada za daleki efekt przewrotu dokonanego przez wielkiego florentczyka i odejścia od klasycznej koncepcji cnót, jest swego rodzaju niezdolność do jednoznacznego, pozbawionego niuansowania tez $\mathrm{i}$ "drugiej strony", oceniania takich zjawisk politycznych jak tyrania ${ }^{29}$. To właśnie pokazuje bogata, erudycyjna książka Piekarskiego, której nie będzie mógł pominąć żaden polski autor, zajmujący się myślą Machiavellego z perspektywy filozofii polityki.

\section{On tyranny and political virtue. Notes in the margin of Romuald Piekarski's book Koncepcja cnót politycznych Machiavellego na tle elementów klasycznej etyki cnót (Machiavelli's Concept of Political Virtues against the Background of the Classical Virtue Ethics)}

\section{Keywords}

Niccolò Machiavelli, political virtues, tyranny, Romuald Piekarski, virtue ethics, political discourse

The article presents the most recent Polish analyses concerning the thought of Niccolò Machiavelli on the background of trends in the contemporary international literature on this thinker, focusing on Romuald Piekarski's book Koncepcja cnót politycznych Machiavellego na tle elementów klasycznej etyki cnót (Machiavelli's Concept of Political Virtues against the Background of the Classical Virtue Ethics, Gdańsk 2007). The author points out that Piekarski's work uses the methodol-

29 Piekarski twierdzi, że aby dać odpór tym wpływom doktryny Machiavellego, trzeba odbudować - może z jakimiś modyfikacjami - klasyczną teorię cnoty. Punktem wyjścia do tego mogłyby być choćby dociekania Galstona, Michaela Walzera czy też Alasdaira MacIntyre'a, a zatem przede wszystkim filozofów wiązanych z komunitaryzmem. Zob. ibidem, s. 456. Warto tutaj wspomnieć, że komentowany autor już wcześniej zastanawiał się nad znaczeniem cnót politycznych dla dawnych i współczesnych społeczeństw. Por. R. Piekarski, Czy istnieja cnoty specyficznie polityczne?, w: Cnoty polityczne - dawniej i obecnie. Moralne źródła polityki, red. R. Piekarski, Gdańskie Towarzystwo Naukowe, Gdańsk 1997, s. 59-87. 
ogy appropriate to the philosophy of politics, while the important monograph by Igor Kąkolewski, based on modern methodology of the study of political discourse, seeks to reconstruct an image of tyranny in the political culture of the Renaissance, and the book by Piotr Kimla devoted to political realism utilizes fairly typical methodological assumptions for the studies of political and legal thought. While in Piotr Kimla's opinion Machiavelli is a "philosopher of security" seeking to stabilize the state with a strong power, Piekarski regards Machiavelli as a philosopher whose postulates assume the superiority of foreign policy over domestic one, and thus lead the unsettling of the political institutions. In turn, Kąkolewski argues that Machiavelli's works are the key to understanding the sixteenth-century discourse on tyranny, which began the process - culminating in the nineteenth century - of axiological neutralization of such terms as "dictatorship" or "despotism". Romuald Piekarski's analyses, though carried out from a completely different point of view, correspond with those theses. According to Piekarski (who refers to famous Leo Strauss' thoughts), Machiavelli was a thinker who broke with the classical, i.e. antique and Christian, concept of virtue in politics, and the contemporary research on politics which assumes refraining from value judgment and axiological pluralism is a specific legacy of Machiavelli's approach. Following the considerations of Piekarski and Kąkolewski, the author of the article states that distant heritage of that approach is a kind of inability of contemporary reflection on the politics to explicitly, i.e., in an unambiguous manner, asses such political phenomena as tyranny. 